\title{
Silmät auki, suomen kielestä kiinnostunut!
}

Ville Eloranta ja JaAkKo Leino: Sanaiset kansiot. Suomen kielen vaietut vaiheet. Gaudeamus, Helsinki 2017. 240 s.

Ville Elorannan ja Jaakko Leinon Sanaiset kansiot (2017) kertoo alaotsikkonsa perusteella suomen kielen vaietuista vaiheista. Takakansiteksti luonnehtii näitä vaiettuja vaiheita yllättäviksi ja oudoiksikin yksityiskohdiksi, jotka voivat muuttaa käsityksiämme tutuista kielen ilmiöistä ja kielen kehityksen vaiheista. Teoksessa on lyhyitä artikkeleita, jotka ryhmittyvät viiden otsikon alle: otsikot ovat Kieli kartalla, Tekstejä taivaan ja maan väliltä, Politiikkaa ja muita intohimoja, Normin jäljillä, kieliopin kannoilla ja Kieli virtaa ja kiertää. Kirjoittajia ei eritellä, vaan tekstit ovat ikään kuin Elorannan ja Leinon yhteisiä. Kirjoittajat käsittelevät monenlaisia aiheita ja pyrkivät kirjoittamaan yleistajuisesti. Kirjan takakansi määrittelee kohderyhmäksi kieleen intohimoisesti suhtautuvat tai kaikki kielestä ja sen kummallisuuksista kiinnostuneet. Teos on tietokirja, mutta sen voi nähdä myös kirjoittajien henkilökohtaisensa puheenvuorona. Ville Eloranta esitellään kirjan lopussa Helsingin Sanomien toimittajaksi ja kielenhuoltajaksi sekä median edustajaksi suomen kielen lautakunnassa. Jaakko Leino on Helsingin yliopiston suomen kielen professori ja suomen kielen lautakunnan puheenjohtaja. Tekstit käsittelevätkin paljon kielenhuoltoa ja median kieltä. Kirjoittajat ottavat henkilökohtaisesti kantaa mutta esittelevät myös esimerkiksi suomen kielen lautakunnan perusteluja.

Sanaiset kansiot käsittelee ajankohtaisia suomen kielen ilmiöitä ja keskusteluja. Kirjoittajien tavoitteena on katsoa asioita kielen kehityksen ja historian näkökulmasta ja avata samalla silmiä uudenlaisille tulkinnoille kielestä ja sen asemasta kansakunnan historiassa ja tulevaisuudessakin. Kun aiheet liikkuvat uralilaisten kielten alkulähteiltä vaikkapa tekeillä olevan suomi-somalisanakirjan toimitustyöhön, kirjassa käsitellään monenlaisia aikatasoja ja kielen kerrostumia. Lukijasta on hauska huomata, että välillä uudeksi sanaksi katsotaan esimerkiksi $1800-$ luvun uudissana tasavalta ja toisessa tekstissä taas pohditaan selfie-sanan käyttöä 2010-luvun suomen kielessä. Artikkelit pyrkivät käsittelemään kirjoittajia itseään kiinnostavia kielihavaintoja mutta rakentamaan myös kokonaisuutta, jossa etenkin suomen kielen moninaisuus tulee esille osana yhteiskuntaa ja kansallisen identiteetin rakentamista. Tämä näkyy jo teoksen esipuheessa, jossa kirjan innoittajiksi nimetään suomen kieli, satavuotias itsenäinen Suomi ja Suomen kansa (s. 10).

Otsikko Kieli kartalla kokoaa yhteen tekstejä, jotka käsittelevät suomen kielen suhdetta sukukieliin ja esittelevät nykyistä tietämystä kielisukulaisuuden ja geneettisen sukulaisuuden eroista ja suomalaisten alkuperästä. Samalla pohditaan murrealueita ja esimerkiksi länsi- ja itäsuomalaisten eroja ja yhtäläisyyksiä. Eloranta ja Leino muistuttavat, että kansallinen identiteetti rakentuu monenlaisista aineksista eivätkä suomalaiset ole vanhastaankaan olleet perimältään kovin yhtenäisiä. Kirjoittajat eivät ota suoraan kantaa nykykeskusteluun vaan antavat lukijan oivaltaa, miten historiaa kannattaisi huomioida esimerkiksi, kun määritellään, ketkä ovat suomalaisia. Kielen ja kansan alkuperän jälkeen kielikartaksi hahmottuvat esimerkiksi Helsingin slangin variaatio, paikannimien kertomat tarinat kielen ja asutuksen historiasta, sukunimijärjestelmän kehittyminen sekä yritysnimien perinteet ja uudet suomen kieleen huonosti istuvat kansainvälisyyttä tavoittelevat yritysnimet. Kirjan yhtenä tavoitteena on saada lukija pohtimaan uudelleen kielen historian sankaritarinoita ja romantisoituja käsityksiä. Tästä onnistunut esimerkki on suomen kielen ja yleensä kielten ominaispiirteitä käsittelevä teksti Eskimot lumessa, 
suomalaiset saunassa. Luvun lopussa esitellään vielä suomi-somali-sanakirjan toimitustyötä. Somalilla ja suomella ei lähtökohtaisesti ole kielinä mitään yhteistä, mutta kun kieliä tarkastellaan sanatasolla, niissä voi olla yllättäviä yhtäläisyyksiä, kuten suomen sanassa koulu ja somalin sanassa iskuul 'koulu'.

Kokonaisuus Tekstejä taivaan ja maan välillä aloittaa Raamatun suomennoksista ja vanhasta kirjasuomesta. Sen jälkeen tarkastellaan Raamatusta periytyviä ilmaisuja ja kirjakielen laajentumista uskonnollisesta käytöstä laaja-alaiseksi sivistyskieleksi. Seuraavaksi kirjoittajat esittelevät sanomalehtien historiaa ja 180o-luvun sanomalehtien uutisaiheita. Vaikka nykysanomalehden tekstilajit, tyyli ja tavoitteet ovat varsin toisennäköisiä kuin 180o-luvun alun lehtien, lehtien uutisaiheet ovat yllättävän samantapaisia. Nykyisiä mediatekstejä käsitellään kielenhuollon näkökulmasta, sillä toimittajien kieli on usein suurennuslasin alla, on sitten kyse normikielestä tai esimerkiksi muoti-ilmauksista. Kirjoittajat kehottavat suhtautumaan ymmärtävästi kiireessä työtään tekeviin toimittajiin ja huolimattomuusvirheisiin. Yksi kirjan tärkeimmistä tavoitteista onkin saada intohimoisesti kieleen suhtautuvat ymmärtämään kömmähdyksiä ja erilaisia kielenkäytön tilanteita, muuttuvaa kieltä ja päivittyviä normeja. Sanakirjojen näkökulmasta kielen muuttumista tarkastelee Nykysuomen sanakirjaa esittelevä teksti. Tässäkin tavoitteena on havainnollistaa lukijoille, miksei Nykysuomen sanakirja nimestään huolimatta enää kuvaa nyky-yleiskielen sanastoa. Seuraavaksi kirjoittajat pohtivat suomen kielen sanojen määrää ja kielen elinvoimaisuutta tulevaisuudessa, jos suomen kieli menettää esimerkiksi asemansa tieteen kielenä. Kokonaisuuden viimeisessä artikkelissa tarkastellaan kielen merkitystä itsenäisyyden ja kansallisen identiteetin rakentajana ja muistutetaan teksteistä, joilla on erityinen kansallinen merkitys. Lähtökohta on kielessä, mutta kieli vie kirjoittajat käsittelemään myös poliittisesti tärkeitä kysymyksiä Suomen rakentamisesta ja kansallisista tavoitteista. Kirjoittajat ottavat vahvastikin kantaa, mutta kannanotot on perusteltu ja kirjattu maltillisen asiallisesti, mikä on kirja ehdoton suola ja ansio.

Politiikkaa ja muita intohimoja -kokonaisuudessa käsitellään Mikael Agricolan äidinkielen merkitystä ja kirjakielen ja uskonpuhdistuksen kytköstä. Kirjoittajat nostavat esiin maan kaksikielisen historian tärkeyden ja herättelevät esimerkiksi nykyisiä päättäjiä ja kansalaisia yleisemminkin tarkastelemaan ruotsin kielen asemaa uudenlaisesta näkökulmasta. Toisaalta kirjoittajat nostavat voimakkaasti esiin Agricolan työn yhteyden uskonpuhdistukseen ja kuninkaan valtaan, vaikka myöhemmin ruotsalaisten alistamispyrkimys rakensikin pohjan itsenäiselle Suomelle ja yhtenäiselle kansalle ja kirjakielelle. Agricolasta päästään kielen muihin suurmiehiin ja jopa humanismin merkitykseen kansakunnan rakentamisessa. Luontevasti historian jatkumoon yhdistyvät nykykäsitykset lukemisesta; kirjoittajat haluavat puolustaa lukemisen tärkeyttä ja ottaa kantaa sen puolesta, että lukeminen on tärkeä osa työelämätaitoja myös miehille. Näkökulma on uudenlainen, vaikka opettajien huolta poikien lukuharrastuksen hiipumisesta onkin käsitelty mediassa paljon. Lukemisella on yhteys taitoon käyttää kieltä, ja kyky ilmaista itseään kirjoittamalla on yksi keskeinen tapa käyttää valtaa. Eloranta ja Leino muistuttavat, että vallankäyttäjät ovat myös taitavia kielenkäyttäjiä. Vallan ja poliittisen kielenkäytön lisäksi kokonaisuudessa käsitellään suhtautumista lainasanoihin ja esitellään yrityksiä korvata lainasana omaperäisellä ilmauksella. Kirjoittajat muistuttavat, ettei vieraista aineksista puhdasta kieltä ole olemassa. Luvun lopussa tarkastellaan myös politiikan kieltä ja sivutaan kielestä käytyä nykykeskustelua ja keskustelun ongelmia ajankohtaisten esimerkkien kautta. Lopuksi esitellään vielä oikeusasiamiehen toimintaa ja mahdollisuuksia ohjata kielenkäyttöä viranomaisena. 
Otsikon Normien jäljillä, kieliopin kannoilla alle kirjoittajat ovat koonneet sekä kielioppien kirjoittamista että normittamisen historiaa ja vähän nykypäivääkin käsitteleviä tekstejä. Tärkeintä lienee hahmottaa, mihin kielenohjailua ja kielioppeja on tarvittu ja tarvitaan. Ensin lukijaa viihdytetään kiistoilla, joita kärkkäät kielimiehet Lauri Kettunen ja E. A. Saarimaa kävivät ennen 1900-luvun puoliväliä. Kiistojen esittely kuitenkin havainnollistaa yhtä kielenohjailun keskeistä periaatetta, kompromisseja ja yleisesti hyväksyttävien vaihtoehtojen valintaa. Kirjoittajat huomioivat eri-ikäiset lukijat kirjoittaessaan kieliopin kategorioista sekä nykynimityksillä että aiemmin vakiintuneesti käytössä olleilla nimityksillä, esimerkiksi mainitsemalla infinitiivien kohdalla sekä kolmannen infinitiivin että MA-infinitiivin. Lukijalle myös perustellaan kieliopin opiskelun merkitystä ja itseisarvoa osana suomen kielen ominaislaadun tuntemista. Kielioppiaiheiden käsittely haastaa lukijan aiempaa kielitietoa, sillä esimerkiksi astevaihtelusta on vaikea kirjoittaa yksinkertaisesti. Lukija tarvitsee ainakin kiinnostusta hahmottaa, mitä vaikkapa sulautuminen ja astevaihtelukehityksen eri vaiheet ovat. Turhia termejä kirjoittajat kuitenkin välttävät onnistuneesti. Kokonaisuudessa käsitellään myös joitakin suomen kielen lautakunnan viime vuosina tekemiä suosituksia: laajimmin näistä esitellään evankelisluterilainen-sanan kirjoitusasuja ja alkaa tekemään rakenteen hyväksymistä. Kirjoittajat pyrkivät selittämään ja perustelemaan nykyistä kielenohjailua ja suositusten taustalla olevia periaatteita. Erityisesti he haluavat kumota väitteen kielenohjailun lepsuudesta, sillä normit ovat muuttuneet aina ja monet normit ovat viime vuosinakin säilyneet muuttumattomina. Kielenhuollon periaatteita on kiteytetty kirjaan varsin onnistuneesti, mikä on kirjoittajien erityisosaamisen ansiota. Perusteluista esiin nousee kieliyhteisön enemmistön kannan kuunteleminen. Tämä on kielenohjailun periaatteena ollut olemassa aiemminkin, mutta enemmistön ääni on usein jäänyt arvovaltaisten kantojen alle. Esimerkiksi alkaa tekemään -keskustelussa kritisoijat pitivät huonona asiana, että lautakunta taipui "joukkovoiman edessä" (s. 196), vaikka nykyisin yksi keskeinen periaate uudistaa normeja on muuttaa ne vastaamaan kielenkäyttäjien enemmistön tapaa käyttää jotakin rakennetta, kirjoitusasua tai muotoa.

Kieli virtaa ja kiertää -kokonaisuudessa palataan lainasanoihin ja poimitaan tarkasteltavaksi kielikeskusteluissa esillä olleita ilmiöitä, kuten sosiaalisen median kieltä. Lainasanojen tarkastelu keskittyy uusiin lainoihin, kuten selfie, mutta palaa vielä ajatukseen, että lainoja on kielessä ollut aina ja lainoja voivat olla myös hyvin keskeiset tai jokapäiväiset kielen sanat. Kielen muuttumista käsitellään myös merkitystenmuutosten ja esimerkiksi käännöslainojen ja yritysnimien kirjoitusasujen avulla. Kuriositeetteina tarkastellaan ääntä jäljittelevää ja muuta kuvailevaa sanastoa ja alatyylistä sanastoa. Lopuksi kirjoittajat pohtivat vielä nuorisokielen kirjoitusasuja, joissa esimerkiksi $x$ on yleiskieltä käytetympi kirjain. Kirja loppuu pohdintaan $x$-kirjaimen tulevaisuudesta yleiskielessä, kun se jo sujuvasti ja neutraalisti esiintyy monissa lainasanoissa.

Elorannan ja Leinon Sanaiset kansiot on kiinnostava ja monipuolinen esitys suomen kielen historiasta, kehityksestä ja yleiskielen olemuksesta. Kirjassa ei käytetä lähdeviitteitä, mutta kirjoittajat viittaavat tarpeen mukaan tutkijoihin ja mainitut tutkimukset ja muutakin kirjallisuutta on listattu kirjan loppuun. Paikoin lukijan iloksi olisi kuitenkin voinut kirjata lisääkin lähteitä tai lukuvinkkejä. Kirjan parasta antia ovat uudenlaiset, silmiä avaavat näkökulmat, joilla on monenlaisia yhteyksiä nykykeskusteluun. Kirjoittajat ovat päätyneet julkaisemaan tekstit kirjana. Monet tekstit ovat kolumnimaisen lyhyitä, ja Eloranta onkin käsitellyt osaa aiheista myös Helsingin Sanomissa (esimerkiksi HS 13.1.2015, HS 20.3.2015, HS 28.2.2016, HS 19.5.2016 ja HS 3.10.2016). Kirjoituksia ei ole kuitenkaan julkaistu kirjassa sellaisenaan, ja sikäli teos poikkeaa perinteestä painaa kirjaksi muualla aiemmin julkaistuja kielijuttuja (tätä perinnettä edustavat 
esimerkiksi Erkki Lyytikäisen (1995) Bikinirajaus ja Lari Kotilaisen ja Annukka Vartevan (2002) toimittama Maailman vaikein kieli). Osin ajankohtaiset aiheet sopivat kuitenkin paremmin $\mathrm{Hel}$ singin Sanomien palstoille kuin kirjaksi. Kirjan riskinä on, etteivät lukijat myöhemmin muista käsiteltyä ajankohtaiskeskustelua lainkaan. Toivottavasti nykymaailmassa voi virittää keskustelua ottamalla kantaa asioihin kirjan muodossa, sillä kirjan tiedon ja sanoman toivoisi tavoittavan myös muita kuin lukemiseen ja kieleen intohimoisesti suhtautuvia.

PÄIVI LAINE

paipel@utu.fi

Suomen kieli ja suomalais-ugrilainen kielentutkimus 20014 Turun yliopisto

\section{Lähteet}

HS $=$ Helsingin Sanomat .

HS 13.1.2015 = ElORANTA, VILLE: Kielitoimisto suosittaa - vai suosittaako?

HS 20.3.2015 = ElORANTA, VILLE: Snagari vai snägäri? Ihan sama - slangia saa väännellä.

HS 28.2.2016 = ElORANTA, VILLE: Härkäsestä tuli kärpänen - svetisismeistä kiihkoilu ei ole enää kovin hedelmällistä.

HS 19.5.2016 = ElORANTA, VILLE: Kirkko näytti viivan paikan.

HS 3.10.2016 = ElORANTA, VILLE: Hyvä yritysnimi voi syntyä vahingossa - ja huono pitkällisen harkinnan jälkeen.

Kotilainen, Lari - Varteva, AnnukKa 2002: Maailman vaikein kieli. SKST 882. SKS, Helsinki.

LYYTIKÄINEN, ERKKI 1995: Bikinirajaus. Näkökulmia kieleen. SKST 623. SKS, Helsinki.

SKS = Suomalaisen Kirjallisuuden Seura.

SKST $=$ Suomalaisen Kirjallisuuden Seuran Toimituksia. 